\title{
Physico-Chemical Evaluation of Drinking Water Treatment Plant and Sand Filter Backwashing Water for Possible Recycling: A Case Study
}

\author{
Hussein I. Abdel-Shafy ${ }^{1 *}$, Mohamed A. Salem ${ }^{2}$, Mona S. M. Mansour ${ }^{3}$, Mohamed \\ A. El-Khateeb ${ }^{1}$, and Sally H. Abdel-Shafy ${ }^{4}$ \\ ${ }^{1}$ Water Research \& Environmental Science Department, National Research Center, \\ Dokki, Cairo, Egypt. \\ ${ }^{2}$ General Manager, Serabium Wastewater treatment Plant, Ismailia, Egypt. \\ ${ }^{3}$ Analysis \& Evaluation Department, Egyptian Petroleum Research Institute, 1 Ahmed \\ El-Zomor Street, Nasr City, Cairo, Egypt. \\ ${ }^{4}$ National Research Center, Dokki, Cairo, Egypt.
}

\begin{abstract}
A COMPARATIVE chemical study was carried out to evaluate the physical, chemical and biological characteristics of a selected Drinking Water Treatment Plant (DWTP) in Egypt. The evaluation includes the inlet fresh water of the Canal, the produced drinking water (DW) and the sand filter backwashing water (BWW). An extensive sampling program was carried out to collect water from each of these studied points. All experimental studies were carried out according to APHA. The results showed that the Canal water is not contaminated by any hazardous pollutants, and the conventional treatment system of the plant could successfully produce good quality of DW that cope with the Egyptian, WHO and EPA regulations. The characteristics of the BWW showed slight increase of TSS, turbidity and aluminum. This water consists of $19.5 \%$ of the produced DW and is daily discharged to the Canal water way. Thus, it is a source of contamination to the Canal. Several recommendations are included in this study to the decision makers that can save $20 \%$ of the wasted water in one hand and protect the waterways of the Canal on the other hand. The pre-chlorination of the fresh Canal water in the DWTP should be replaced by ozone instead of chlorine to avoid any formation of trihalomethanes that might be available in the Canal. Meanwhile, the Canal should be prevented from the disposal of the BWW. Thus, the BWW should not be wasted; it should be reused for other purposes such as irrigating the green area around the DWTP, for flushing, or treated by using simple system and recycled. This will prevent the ecosystem of the Canal in one hand and can be as additional water resources on the other hand. The chemical characteristics of the BWW should be carriedout periodically along with the surface and the produced drinking water to ensure the suitability of BWW for recycling.
\end{abstract}

Keywords: Drinking water treatment plant in Egypt, Backwashing water, Sand filter, Recycling of water, Canal water, Drinking water, Water resources in Egypt.

\section{Introduction}

Water is one of the most precious natural sources for the human and all living creations on earth. Preservation and protection of these sources is essential for our continuation as human being. However, depletion and misuse of such precious natural sources have been practiced during the last few decades $[1,2]$. In the arid and semi-arid areas; as the case in Egypt; the importance of water resources is more crucial to life [3]. Water quality degradation in these areas as well as certain parts in the world was reported due to the rapid development of industries, agriculture and urbanization activities during the last few decades $[1,2,4,5]$. Groundwater in Egypt is considered fossil non-renewable resources [6]. On the other hand, rainwater is very limited in Egypt with the exception of the North coast [7].

Source and quality of drinking water receives considerable attention due to the impact on human health [3]. Nevertheless, mismanagement and misuse of water resources have resulted in a rapid decline the quality and supply of water as well as widespread of diseases [7]. On the other

*Corresponding author e-mail: hshafywater@yahoo.com

DOI: $10.21608 /$ ejchem.2018.3731.1316

(C2017 National Information and Documentation Centre (NIDOC) 
hand, water quality guidelines can be employed strictly to identify constituents of concern in water quality and resources, to determine the suitability of treatment for drinking purposes [8]. In this respect the physical, chemical and microbiological characteristics of water must be determined in a continuous way $[2,9,10]$. In addition, the need for guidelines of the water inlet and the standards for the water quality of the produced drinking water are essential to protect human health. Thus, removal of some chemical constituents and other contaminants must be carried out precisely [10-12].

Therefore, the water quality monitoring program is essential for the protection of freshwater resources [13]. It is necessary to determine the degree of contamination of the surface water that is used for different purposes $[14,15]$. There are several studies conducted on the water quality of the River Nile in Egypt including evaluation of heavy metal and other pollutants [16-18]. It is a crucial issue particularly for a country like Egypt that suffers from deficiency of water resources.

Water supply, therefore, is an important issue that certainly affects the final produced drinking water. Such water supply should be protected to obtain safe drinking water. Increasing this issue is becoming evident in many nations worldwide. From a socio-economic standpoint view, increasing such water resources can strengthen and improve the quality of life to people. In Egypt, we are facing several increasing problems in terms of deficiency of water resources and partially contamination of surface as well as ground waters [20]. Several water bodies receive increasing contamination loads as a result of inadequate treatment wastewater and irresponsible behavior. Due to the climatic change in the world, it was reported that approximately $70 \%$ of the renewable water resources are unavailable or diminished for human use $[1,2]$. Decreasing the quantity of water resources and lack of water suitable for both irrigation and drinking could certainly lead to food shortages that affect health and economy for many countries in the world. Furthermore, water scarcity of several nations can stifle economy, health care and negative impact on the environment. ${ }^{[3]}$ Despite such global water stress and scarcity, human population is in continues increase particularly in the developing countries like Egypt [4]. Consequently, there is an urgent worldwide action to protect and to increase our water resources, particularly in the developing countries.

The aim of the present investigation is to determine the physical, chemical and microbiological characteristics of the raw fresh canal water, the final treated drinking water as well as the sand filter backwashing water in Egypt. The purpose is to determine the efficiency of this important drinking water treatment plant that supplies different areas this drinking water treatment plant (DWTP). The additional purpose is to determine the physical/chemical characteristics of the sand filter backwashing water for possible recycling due to the shortage of water resources in this area. According to these comparative results, conclusion and recommendation could be suggested for better management of this important issue and water quality in Egypt as a guide to the decision makers.

\section{Materials and Methods}

Description of the Studied Drinking Water Treatment Plant

It is the main drinking water treatment plant (DWTP) locates in the North-East of Egypt. It supplies drinking water to the west and east Quanta area in Egypt. This DWTP was constructed directly on a small fresh water Canal that is branched from Ismailia Canal. The source of raw fresh water of Ismailia Canal is the Nile River. The treatment system in this DWTP plant is illustrated in Fig.1. The successive treatment steps at this DWTP are:

İnlet of raw fresh water was pumped through pipe of $4.5 \mathrm{~m}$ width at the depth of $3-3.5 \mathrm{~m}$ from the Canal to the plant.

1. The fresh waters are to be pumped into two settling tanks to remove the coarse sand or small gravels. The capacity volume of each settling tank is $150 \mathrm{~m}^{3}$ volume. Chlorine water and liquid alum are to be injected into the outlet of each settling tank at the dose of 3.4 $\mathrm{mg} / \mathrm{l}$ chlorine and $50 \mathrm{mg} / \mathrm{l}$ alum followed by complete mixing process.

2. The injected water is to be directed into two coagulation and flocculation large tanks.

3. The flocculated water is to be directed to two sedimentation tanks, where all the coagulated and flocculated suspended solids and particlates are to be settled down.

4. Finally the settled treated water is to be filtred by 6 large sand filters to remove all the fine non-settled particles.

5. The filtered water is post-chlorinated and directed to the two large storage tanks and to be distributed to supply the surrounded areas with treated drinking water.

6. This DWTP is operated 24 hours /day and produces about 60 litre / sec. The total daily produced water is around $5,184 \mathrm{~m}^{3} /$ day treated drinking water.

\section{Experimental Work}

An extensive sampling program was designed to collect different water monthly samples for a period of five months continuously. The samples were: raw canal water, final treated drinking water and the "backwashing" water. All samples were 
manually collected in two liter polyethylene bottles for physical and chemical characteristics. For the microbiological characteristics one sterile liter glass bottles were used. Microscopic examination for living microorganisms including (protozoa, blueish green algae) was also examined in the final treated drinking water. The collected samples were freshly transported to our laboratories in icebox at temperature of $4^{\circ} \mathrm{C}$. Temperatures and free residual chlorine concentrations were immediately determined on spot and before storing according to procedures in the Standard Methods [APHA, 2005] [21]. Other physical, chemical, and microbiological characteristics as well as the microscopic examination were carried out according to procedures described in the Standard Methods for the Examination of Water and Wastewater (APHA)[21]. Each result presented in this investigation is the average of 7 sequence readings of each five samples.

Microbiological characteristic
Detection of the Total count of Bacteria, Total Coli form, coli form bacilli and the other pathogenic bacteria were carried out according to the described procedures in (APHA)[21].:

\section{Microscopic examination}

Detection of the living microorganisms (protozoa, blueish green algae) was made without any treatment. Few drops of water samples were placed on a glass slide and were examined by light Microscope using high power.

\section{Results and Discussion}

Physical and Chemical Characteristics of the Raw Canal Water:

This study was conducted through the entire sampling program. The results (Table 1) indicate that this fresh water is suitable as a source for treatment to produce drinking water. The canal water is free from hazard contaminants and the mean values reveal good quality of fresh water. The Canal water

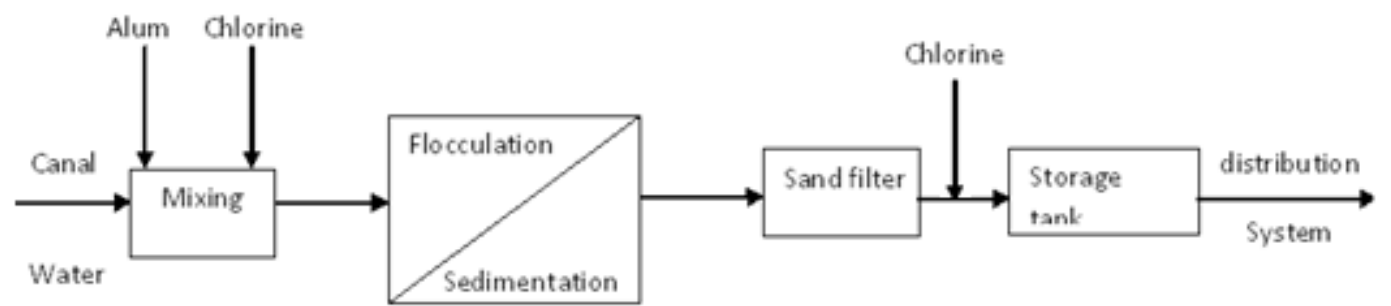

Fig. 1. Successive treatment steps in the Drinking Water Treatment Plant, the pre-and post-chlorination are indicated.

TABLE 1. Physical and chemical Characteristics of the raw Canal fresh water.

\begin{tabular}{|c|c|c|c|c|}
\hline \multirow{2}{*}{ parameters } & \multirow{2}{*}{ Unit } & \multicolumn{3}{|c|}{ Raw Canal Water } \\
\hline & & Max. & Min. & Mean \pm S.D. \\
\hline $\mathrm{pH}$ & & 7.8 & 7.7 & $7.76 \pm 0.05$ \\
\hline TDS & $\mathrm{mg} / \mathrm{l}$ & 348 & 234 & $310 \pm 58.04$ \\
\hline $\mathrm{EC}$ & $\mu \mathrm{mhos}$ & 390 & 527 & $496 \vee ノ, \wedge \pm$ \\
\hline Turbidity & NTU & 12.9 & 6.7 & $9.7 \pm 3.1$ \\
\hline TSS & $\mathrm{mg} / 1$ & 87.3 & 68.9 & $73.8 \pm 9.5$ \\
\hline T. Hard. & $\mathrm{mg} / \mathrm{l}$ as $\mathrm{CaCO}_{3}$ & 149 & 141 & $144.6 \pm 4.0$ \\
\hline Alkalinity & $\mathrm{mg} / \mathrm{l}$ & 160 & 129 & $148 \pm 15.6$ \\
\hline Chlorides & $\mathrm{mg} / \mathrm{l}$ & 58.3 & 51.1 & $54.3 \pm 3.6$ \\
\hline Sulfates & $\mathrm{mg} / \mathrm{l}$ & 39 & 44 & $43.6 \pm 2.78$ \\
\hline Nitrates & $\mathrm{mg} / \mathrm{l}$ & 0.24 & 0.07 & $0.20 \pm 0.09$ \\
\hline Nitrites & $\mathrm{mg} / \mathrm{l}$ & Nil & Nil & Nil \\
\hline $\mathrm{Al}$ & $\mathrm{mg} / \mathrm{l}$ & 0.09 & 0.08 & $0.08 \pm 0.006$ \\
\hline Sodium & $\mathrm{mg} / \mathrm{l}$ & 24.9 & 20 & $21.8 \pm 2.48$ \\
\hline Potassium & $\mathrm{mg} / \mathrm{l}$ & 3.0 & 2.6 & $2.86 \pm 0.2$ \\
\hline Calcium & $\mathrm{mg} / \mathrm{l}$ & 47.5 & 44.0 & $45.8 \pm 1.75$ \\
\hline
\end{tabular}


is characterized by low levels of turbidity, total hardness, alkalinity, chlorides, sulfates and nitrates.

\section{Drinking Water}

The physical, chemical and bacteriological characteristics of the produced drinking water are given in Table 2. These results indicate that the quality of the produced drinking water is within the good quality [22, 23]. The hardness (total, $\mathrm{Ca}$ and $\mathrm{Mg}$ hardness) indicates that it is a soft water. The anions including chlorides and sulfates namely: 53 and $39 \mathrm{mg} / \mathrm{l}$ respectively, are low. The nitrogenous compounds including nitrates, nitrites and ammonium compounds are all Nil. The average amount of the residual chlorine was $1.9 \mathrm{mg} / \mathrm{l}$ that indicate a safe guard to this water during both storage and distribution systems. The microscopic examinations for living microorganisms including (protozoa, blueish green algae) were also Nil. The total coliforms are always less than $<1.1$ as total count, and the fecal coliforms are all Nil which indicate that the added chlorine is sufficient to get rid of any coliform bacterial contamination as well as the other living microorganisms; if there is any. In general, the produced treated drinking water is within the permissible level and within the good quality according to the Egyptian regulations (WHO and EEAA) [19, 23].

\section{Back washing water}

The normal practice of the conventional Drinking Water Treatment Plants (DWTP) worldwide is to clean their sand fiter and to remove the suspensions and precipitants via backwashing process. Thus, they consume part of their produced drinking water to achieve this backwashing process. İn the present DWTP the 6 sand filters are backwashed every eight hours (i.e. three times per day). This backwashing process consumes large quantity of water. The estimation amount of the backwashing water is about $1000 \mathrm{~m}^{3} / \mathrm{d}$ (i.e. about $19.3 \%$ of the produced drinking water). This amount of backwashing water is wasted by draining back to the canal waterway. Therefore, it was essential to study the quality of this backwashing water in terms of the physical and chemical characteristics to determine the possibility of recycling such as wasted water.

TABLE 2. Physical, chemical and bacteriological characteristics of the final treated drinking water.

\begin{tabular}{|c|c|c|c|c|c|c|c|}
\hline Parameters & Units & Sample (1) & Sample (2) & Sample (3) & Sample (4) & Sample (5) & Average \pm S.D. \\
\hline Color & & Colorless & colorless & colorless & colorless & colorless & Colorless \\
\hline Odor & & Odorless & odorless & odorless & odorless & odorless & Odorless \\
\hline Taste & & Tasteless & tasteless & tasteless & tasteless & tasteless & Tasteless \\
\hline $\mathrm{pH}$ & & 7.38 & 7.50 & 7.65 & 7.35 & 7.60 & $7.55 \pm 0.13$ \\
\hline E.C. & $\mu \mathrm{mhos}$ & 535 & 539 & 593 & 587 & 573 & $565 \pm 27.0$ \\
\hline Turb. & NTU & 0.87 & 0.58 & 0.57 & 0.56 & 0.72 & $0.63 \pm 0.13$ \\
\hline TDS & $\mathrm{mg} \cdot \mathrm{L}^{-1}$ & 342 & 358 & 379 & 367 & 341 & $364 \pm 16.3$ \\
\hline $\begin{array}{l}\text { Residual } \\
\text { Chlorine }\end{array}$ & $\mathrm{mg} \cdot \mathrm{L}^{-1}$ & 1.75 & 0.75 & 2.25 & 1.70 & 0.77 & $1.25 \pm 0.6$ \\
\hline Alkalinity & $\mathrm{mg} \cdot \mathrm{L}^{-1}$ & 145 & 170 & 180 & 155 & 163 & $166 \pm 13.5$ \\
\hline T.Hard. & $\mathrm{mg} \cdot \mathrm{L}^{-1}$ & 158 & 176 & 174 & 165 & 171 & $168 \pm 7.3$ \\
\hline Ca Hard. & $\mathrm{Mg} . \mathrm{L}^{-1}$ & 110 & 116 & 110 & 113 & 114 & $115 \pm 2.6$ \\
\hline Mg Hard. & $\mathrm{Mg} \cdot \mathrm{L}^{-1}$ & 48 & 60 & 64 & 52 & 57 & $53 \pm 6.3$ \\
\hline Chlorides & $\mathrm{mg} \cdot \mathrm{L}^{-1}$ & 45 & 55 & 60 & 58 & 49 & $53 \pm 6.3$ \\
\hline Nitrates & $\mathrm{mg} \cdot \mathrm{L}^{-1}$ & Nil & Nil & Nil & Nil & Nil & Nil \\
\hline Nitrites & $\mathrm{mg} \cdot \mathrm{L}^{-1}$ & Nil & Nil & Nil & Nil & Nil & Nil \\
\hline Sulfates & $\mathrm{mg} \cdot \mathrm{L}^{-1}$ & 25 & 45 & 42 & 45 & 35 & $39 \pm 8.5$ \\
\hline Ammonium & $\mathrm{mg} \cdot \mathrm{L}^{-1}$ & Nil & Nil & Nil & Nil & Nil & Nil \\
\hline $\mathrm{Al}$ & $\mathrm{mg} \cdot \mathrm{L}^{-1}$ & 0.15 & 0.12 & 0.16 & 0.11 & 0.13 & $0.14 \pm 0.02$ \\
\hline $\begin{array}{l}\text { Residual } \\
\text { Chlorine }\end{array}$ & $\operatorname{mg} . \mathrm{L}^{-1}$ & 1.9 & 2.0 & 2.2 & 1.8 & 2.0 & $1.9 \pm 0.14$ \\
\hline Total Coliform & $100 / \mathrm{mL}$ & $<1.1$ & $<1.1$ & $<1.1$ & $<1.1$ & $<1.1$ & $<1.1$ \\
\hline Fecal Coliform & $100 / \mathrm{mL}$ & Nil & Nil & Nil & Nil & Nil & Nil \\
\hline $\begin{array}{l}\text { Microscopic } \\
\text { examination }\end{array}$ & Count & Nil & Nil & Nil & Nil & Nil & Nil \\
\hline
\end{tabular}

EC = Electrical Conductivity, TDS = Total Dissolved Solids, T. Hard. = total hardness, Ca Hard. = calcium hardness, Mg Hard. = magnesium hardness, $\mathrm{Al}=$ residual aluminum,

S.D. $=$ Standard Deviation.

Egypt. J. Chem. 61, No. 6 (2018) 
Consequently, extensive sampling program was set out to study the physical, chemical and microbiological characteristics of raw Canal water, treated drinking water, and the backwashing water at the selected Drinking Water Treatment Plant. The results obtained (Table 3 ) indicate that the backwashing water contains residual amounts of both aluminium and chlorine. Disposing of such wasted water would; certainly; harms the water quality of the Canal. The backwashing water also contains relatively higher amount of suspended solids in correlation to the raw Canal water.

Disadvantages of discharging the backwashing water to the ecosystem of the Canal

1. Large quantities of the backwashing water that was already treated as drinking water is wasted to the Canal. The amount is around $20 \%$ of the total produced water. This water costs money, chemicals, efforts, energy, operation and maintenance. Thus it should not be wasted, particularly for a country like Egypt that will be faced with water crisis.

2. This "backwashing" water is turbid contains considerable amount of total suspended solids, and alum that harms the aquatic lives of the Canal. The ecosystem of the Canal should be protected from such contaminations that might affect the quality of Canal water as well,

3 . Besides, the discharged water contains $5 \%$ of the sludge that produced from the drinking water treatment process. It is mostly the "alum sludge" as valuable materials that could be recycled and reused for other purposes.

4. The physical, chemical and microbiological characteristics of the collected backwashing water samples are given in Table 3.

TABLE 3. Physical, chemical and microbiological characteristics of the backwashing water.

\begin{tabular}{|c|c|c|c|c|c|c|c|}
\hline \multirow[b]{2}{*}{ parameters } & \multirow[b]{2}{*}{ Unit } & \multicolumn{6}{|c|}{ Backwashing water } \\
\hline & & 1 & 2 & 3 & 4 & 5 & $\begin{array}{c}\text { Mean } \\
\pm \\
\text { S.D. }\end{array}$ \\
\hline $\mathrm{pH}$ & & 7.3 & 7.2 & 7.3 & 7.29 & 7.3 & $7.278 \pm 0.04$ \\
\hline TDS & $\mathrm{mg} / \mathrm{l}$ & 299 & 348 & 349 & 294 & 360 & $330 \pm 31.0$ \\
\hline $\mathrm{EC}$ & $\mu \mathrm{mhos}$ & 529 & 489 & 531 & 433 & 533 & $503 \pm 43.2$ \\
\hline Turbidity & NTU & 16 & 12 & 8.3 & 15 & 14.5 & $13.16 \pm 3.1$ \\
\hline TSS & $\mathrm{mg} / \mathrm{l}$ & 106.2 & 99.5 & 102.2 & 88.5 & 97.1 & $98.7 \pm 6.6$ \\
\hline T. Hard. & $\begin{array}{c}\mathrm{mg} / \mathrm{l} \\
\text { as } \mathrm{CaCO}_{3}\end{array}$ & 152.8 & 148.6 & 148 & 151 & 155 & $151.08 \pm 3.0$ \\
\hline Alkalinity & $\mathrm{mg} / 1$ & 168 & 160 & 161 & 166 & 163 & $163.6 \pm 3.4$ \\
\hline Chlorides & $\mathrm{mg} / \mathrm{l}$ & 49 & 54 & 55 & 48 & 59.5 & $53.1 \pm 4.7$ \\
\hline Sulfates & $\mathrm{mg} / \mathrm{l}$ & 53 & 50 & 51 & 56 & 53 & $52.6 \pm 2.3$ \\
\hline Nitrates & $\mathrm{mg} / \mathrm{l}$ & 0.11 & 0.12 & 0.14 & 0.10 & 0.12 & $0.118 \pm 0.01$ \\
\hline Nitrites & $\mathrm{mg} / \mathrm{l}$ & Nil & Nil & Nil & Nil & Nil & Nil \\
\hline $\mathrm{Al}$ & $\mathrm{mg} / \mathrm{l}$ & 0.21 & 0.23 & 0.20 & 0.22 & 0.25 & $0.222 \pm 0.02$ \\
\hline Sodium & $\mathrm{mg} / \mathrm{l}$ & 21.9 & 19.7 & 22.7 & 19.9 & 24 & $21.64 \pm 1.8$ \\
\hline Potassium & $\mathrm{mg} / \mathrm{l}$ & 3.0 & 2.9 & 3.0 & 2.9 & 3.3 & $3.02 \pm 0.1$ \\
\hline Calcium & $\mathrm{mg} / \mathrm{l}$ & 53.4 & 57.1 & 56.5 & 52.0 & 58.0 & $55.4 \pm 2.5$ \\
\hline $\begin{array}{c}\text { Number of } \\
\text { cells or eggs of } \\
\text { Nematode }\end{array}$ & Count/L & Nil & Nil & Nil & Nil & Nil & Nil \\
\hline Sludge \% & $\%$ & - & - & 6.2 & 4.3 & 4.8 & $5.1 \pm 0.7$ \\
\hline
\end{tabular}


From these results (Tables 1, 2 and 3), it can be indicated the following:

1. The Canal water is turbid due to the presence of the natural silt and clay that are originated from the Nile River (Table 1). However, the other physical and chemical characteristics indicate good quality of the natural fresh water free of hazard compounds.

2. All the physical, chemical and microbiological characteristics of the treated drinking water (Table 2) are within the acceptable limits according to the Egyptian EEAA regulations (2000) [23].

3. The backwashing water (Table 3 ) is highly turbid (12.6 NTU), suspended solids (96.4 $\mathrm{mg} / \mathrm{l})$ and consists of high level of aluminum $(0.22 \mathrm{mg} / \mathrm{l})$ as illustrated in Fig. 2. The sulfates are $53.6 \mathrm{mg} / \mathrm{l}$. Nevertheless, the rest of the characteristics are within the permissible limits, but it cannot be accepted as drinking water at all.

4. The backwashing water contains considerable amount of TSS namely $96.4 \mathrm{mg} / 1$ which is higher than the corresponding TSS in the Canal water $(73.8 \mathrm{mg} / \mathrm{l})$.

5. The sludge is mainly suspended solids mixed with traces of alum.

Based on the given results (Table 3) the backwashing water could be simply treated to remove the suspended solids and sludge. The backwashing water can be reused safely as an additional source for treatment along together with the Canal water (i.e. to be recycled safely instead of being wasted and to avoid a source of contamination to the Canal). Meanwhile, the produced sludge can also be reused for other purposes according to our investigation.

However, an important issue should be mentioned here concerning the pre-chlorination of fresh Canal or River water. In most drinking water treatment plants disinfection of water is employed for the purpose of the destruction or inactivation of human pathogens, up to a given level of safety that should be maintained throughout water storage and distribution. The effect of disinfection depends mainly on the strength of the disinfecting agents and the applied process to kill wide variety of the microbial pathogens as well as to maintain residual of such disinfectant agent.

Meanwhile, the disinfection by-products during water treatment are the result of the chemical reaction between the disinfectants and the presence of natural organic matters in raw drinking water. Among the most common chlorine disinfection by-products are Trihalomethanes. These byproducts are well known to be a carcinogenic chemical compound. It was previously reported that Nile water contains reasonable amount of organic compounds that are readily susceptible to be converted to Trihalomethanes in the presence of chlorine. $(3,4,8)$ Accordingly, it is essential to balance between the health risks associated with the consumption of water with high levels of Trihalomethanes with the risk associated with improper disinfection. Therefore, it is much safer to use natural soil or sub-soil passage of raw river water due to its efficiency to remove organic matters, microorganisms and other pollutants. Otherwise, ozone as disinfectant was found to

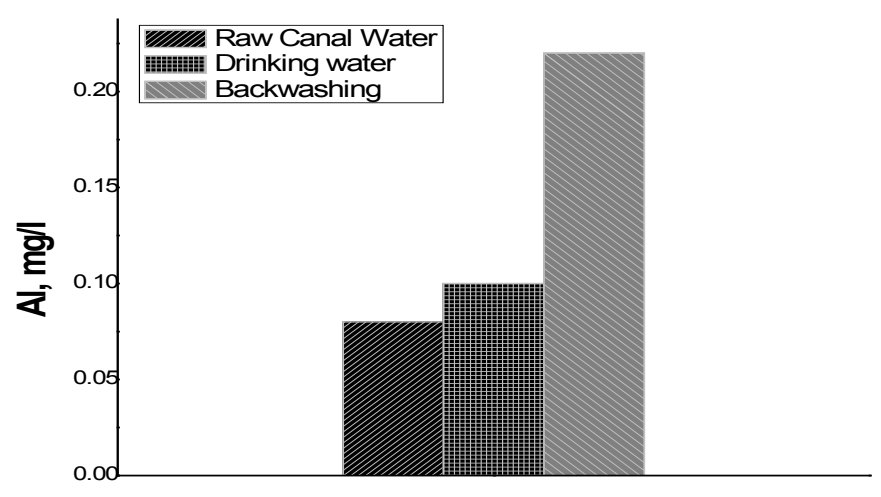

Fig. 2. Level of aluminum in the Canal fresh water, treated drinking water and the backwashing water. 
be safer for drinking water treatment instead of pre-chlorination. The most common processes for water treatment include: Conventional water treatment Plants and Non-Conventional water treatment processes (Department of Municipal Affairs and Environment, 2001; U.S.EPA, 2009) [24].

On the other hand, organic matters are present in all rivers and natural surface water. They produced from the decomposition of aquatic plants and other dead organic matters in the rivers ecosystems. The increased levels of dissolved organic carbon (DOC), total organic carbon (TOC), or water color indicate strong evidence on the presence of reasonable amount of natural organic matter. One of the very effective methods in water treatment to decrease the disinfection by-products is to remove the natural organic matters prior to disinfection $[25,26]$. The removal of such natural organic matters can be achieved successfully by chemical coagulation followed by clarification and precipitation, activated carbon adsorption or membrane technology.

\section{Conclusion}

The Canal fresh water is of good quality in terms of the physical, chemical and microbiological characteristics.

The employed drinking water treatment system is efficient for treatment of the available fresh water. The produced drinking water could cope successfully with the Egyptian, international and WHO regulations $[22,23]$.

The backwashing water should not be wasted; it should be reused for other purposes such as irrigating the green area around the DWTP and/ or for flushing.

The backwashing water can be treated by simple process and recycled back to the DWTP as an additional source of fresh water.

\section{Recommendation}

The pre-chlorination of the fresh Canal water in the DWTP should be avoided and replaced by the use of ozone instead of chlorine to prevent the formation of trihalomethanes compounds. This is mainly due to the presence of the natural organic compounds in the fresh Canal water. However, the post-chlorination should be kept to prevent any unexpected biological contamination.

The canal should be prevented from the disposal of the backwashing water.

The "backwashing" water should be treated by using simple system and recycled and /or reused instead of disposing to the Canal. This will prevent the ecosystem of the Canal in one hand and can be as additional water resources on the other hand.

The chemical characteristics of the backwashing water (BWW) should be carried-out periodically along with the surface and the produced drinking water to ensure the suitability of recycling.

\section{Acknowledgments}

The authors wish to express their deep appreciation to the facilities provided by the project titled "Sustainable Development for Wastewater Treatment and Reuse via Constructed Wetlands in Sinai (SWWTR)" that funded STDF of Egypt.

\section{References}

1. Postel S..L, Entering an era of water scarcity: The challenges ahead. Ecol. Appl. 10, 941- 948 (2000).

2. Shiklomanov I.A., Appraisal and assessment of world water resources. Water Int, 25, 11-32 (2000).

3. Abdel-Shafy H.I., and Aly R.O., Water issue in Egypt: resources, pollution and protection endeavors. Central European J. of Occupational \& Environ. Medicine, 8 (1), 1-21 (2002).

4. Abdel-Shafy Hussein I. and Mona S.M. Mansour Overview on water reuse in Egypt: Present and Future, J. Sustainable Sanitation Practice, 14, 17 25 (2013).

5. Abdel-Shafy H.I. and Aly R.O., Wastewater Management in Egypt. In "Wastewater Reuse-Risk Assessment, Decision-Making and Environmental Security"Mohammed K. Zaidi (Ed) Springer Publisher, Netherland, pp.375-382 (2007).

6. Abdel-Shafy, Hussein I. and Kamel Aziza H. Groundwater in Egypt Issue: Resources, location, Amount, Contamination, Protection, Renewal, Future Overview. Egyptian. J. Chemistry, 59 (3), 321-362 (2016). DOI: 10.21608/ EJCHEM.2016.1085

7. Abdel-Shafy H.I., El-Saharty A.A., Regelsberger M. and Platzer C., Rainwater issue in Egypt: quantity, climatic effect and future overlook. $J$. Mediterranean Marine Science, 11, (2), December, 245-257 (2010).

8. Abdel-Shafy Hussein I., Mansour Mona S.M. and Egypt. J. Chem. 61, No. 6 (2018) 
Abdel-Shafy Sally H., Chemical and Biological Contamination of Drinking Water as Affected by Residual Chlorine Deterioration and Storing Period: Case Study in Sinai, Egypt, Egyptian. J. Chemistry, Article 10,60 (6), 1067-1076 November and December (2017), DOI: 10.21608/ EJCHEM.2017.1488.1106.

9. Abdel-Shafy Hussein I., Salem Mohamed A., Mansour Mona S. M., El-Khateeb Mohamed A., and Abdel-Shafy Sally H., Drinking Water Issue in North-West Sinai: The Problem and Solution in a Case Study, Egyptian. J. Chemistry, 59 (2), 229240 (2016). DOI: 10.21608/EJCHEM.2016.945

10. Bixio D., Thoeye C., Wintgens T., Ravazzini A., Miska V., Muston M., Chikurel H., Aharoni A., Joksimovic D., Melin T., Water reclamation and reuse: Implementation and management issues. Desalination 218,13-23 (2008).

11. Abdel-Shafy Hussein I. and Abdel-Shafy Sally H., Membrane Technology for Water and Wastewater Management and Application in Egypt: Review Article. Egyptian. J. Chemistry, 60 (3), 347-360 May and June (2017), DOI: 10.21608/ EJCHEM.2017.3480.

12. Abdel-Shafy, Hussein I., Chemical Treatment for Removal of Heavy Metals from Industrial Wastewater. Egyptian. J. Chemistry, 58 (1), 1-12 (2015).

13. Pesce S. F., Wunderlin D. A., Use of water quality indices to verify the impact of Córdoba city (Argentina) on Suquía River. Water Research, 34, 2915-2926 (2000).

14. Almeida C. A., Quintar S., Gonzalez P., Mallea M. A., Influence of urbanization and tourist activities on the water quality of the Potrero de los Funes River (San Luis-Argentina). Environmental Monitoring and Assessment, 133, 459-465 (2007).

15. El-Bahy G. S., Ahmed M.A., Abdel-Shafy H.I. and Ibrahim M. A., Role of Industrial Wastewater on the Contamination of River Nile in Greater Cairo, Egyptian Journal of Chemistry, 48, (3), 355-363 (2005).

16. Lasheen M.R., Abdel-Shafy H.I. and Ashmawy A. M., Selected Trace Metals in River Nile Sediments. Bulletin of N.R.C., Egypt, 7, 299-306 (1982).

17. Lasheen, M.R., Abdel-Shafy H.I. and Ashmawy
A. M., Assessment of the Impact of Organic and Inorganic Pollutants on the Water Quality of Ismailia Canal. International Symposium, Alexandria, March, 28-31, (1981).

18. Abdel-Shafy H.I., Abdel-Sabour M.F. and Aly R.O., Adsorption of nickel and mercury from drinking water stimulant by activated carbon. $J$. Environmental Management \& Health, 9 (4), 170175 (1998).

19. WHO (World Health Organization) "Guidelines for drinking water quality, 4th ed. Geneva: WHO, 564p. (2011). ISBN: 9789241548151.

20. Egyptian Ministry of Health, Standards and specifications of water quality for drinking and domestic uses. Internal Report. 1- 8 (2007).

21. APHA, AWWA and WEF, Standard health methods for the examination of water and wastewater. American Public Health Association, 19th Ed., Washington.. (2005).

22. World Health Organization (WHO) "Guidelines for Drinking-water Quality”, set up in Geneva, (1993)

23. EEAA - Egyptian Environmental Association Affair, Law 48, No. 61-63, Permissible values for wastes in River Nile (1982) and Law 4, Law of the Environmental Protection (1994)-updating No.(44), (2000).

24. U S EPA Environmental impact and benefits assessment for final effluent guidelines and standards for the construction and development category. Office of Water, Washington, DC.EPA821-R-09-012 (2009).

25. Richardson Susan D., Plewa, Michael J., Wagner, Elizabeth D., Schoeny, Rita, DeMarini, David M., Occurrence, genotoxicity, and carcinogenicity of regulated and emerging disinfection by-products in drinking water: A review and roadmap for research. Mutation Research/Reviews in Mutation Research. 636 (1-3),178-242(2007).doi:10.1016/j. mrrev. 2007.09.001. PMID 17980649.

26. Winder Chris, The Toxicology of Chlorine. Environmental Research. 85 (2), 105-14 (2001). Bibcode:2001ER....85..105W. doi:10.1006/ enrs.2000.4110. PMID 11161660.

Received 13/5/2018; accepted 18/7/2018) 


$$
\begin{aligned}
& \text { تقييم كيميائى لمياه غسيل المرشحات الرملية لاعادة استخد/مها فى محطات مياه الشرب } \\
& \text { حسين ابر اهيم عبد الثافى1 ، محمد عبد الحميد سالم²، منى سفينة محمد منصور33، محمد على الخطيب1، سالى حسين }
\end{aligned}
$$

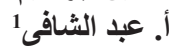

$$
\begin{aligned}
& \text { المركز القومى للبحوث - ش التحرير ـ الدقى ـ القاهرة ـ مصر. }
\end{aligned}
$$

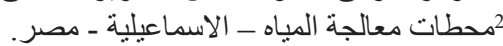

$$
\begin{aligned}
& \text { 3قسم التحليل و التقييم - معهد بحوث البترول - ش احمد الزمر - مدينة نصر - القاهرة - مصر. }
\end{aligned}
$$

دراسة مقارنة لتقييم الخواص الطبيعية، والكيميائية ، والبيولوجية لمياه الثرب لاحد محطات الثيات المعالجة فى جمهورية

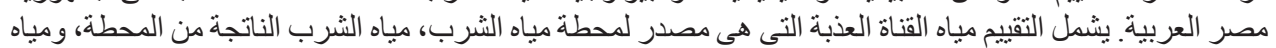

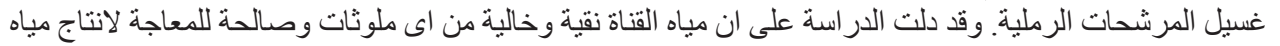

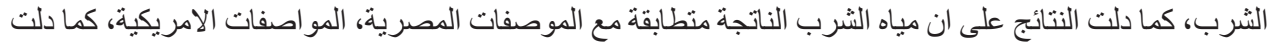

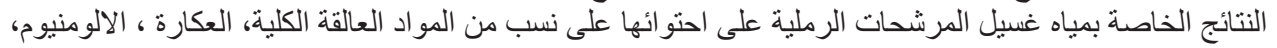

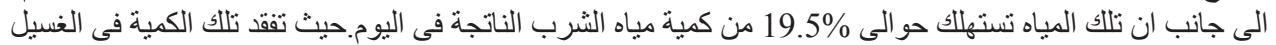

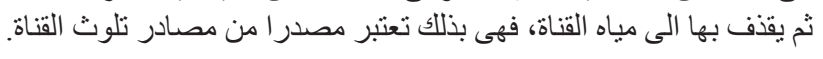

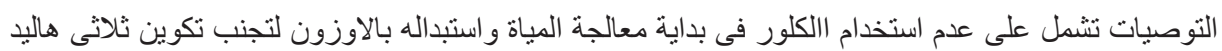

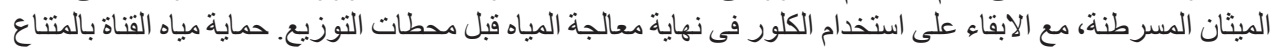

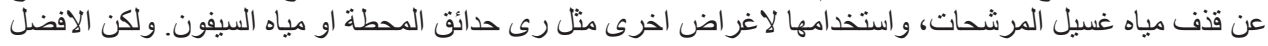

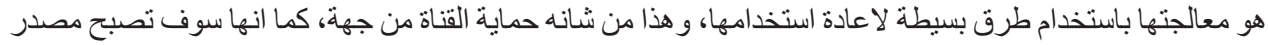

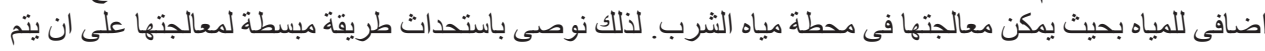
تحليلها دوريا مع مياه القناة ومياه الثرب النانيانة 